Institute of $\mathbf{F}_{\text {ood and }} \mathbf{A}_{\text {gricultural }} \mathbf{S}_{\text {ciences }}$

\title{
Asian Ambrosia Beetle, Granulate Ambrosia Beetle (no official common name), Xylosandrus crassiusculus (Motschulsky) (Insecta: Coleoptera: Scolytidae) ${ }^{1}$
}

\author{
T. H. Atkinson, J. L. Foltz, R. C. Wilkinson, and R. F. Mizell ${ }^{2}$
}

\section{Introduction}

Xylosandrus crassiusculus (Motschulsky) (Coleoptera: Scolytidae) is a minute ambrosia beetle of Asian origin that was first detected in the continental United States near Charleston, South Carolina (Anderson 1974). It apparently has spread along the lower Piedmont region and coastal plain to North Carolina, Louisiana, Florida (Chapin and Oliver 1986, Deyrup and Atkinson 1987), and East Texas (Atkinson, unpublished). It was collected in western Florida in 1983 (Chapin and Oliver 1986), in southern Florida in 1985 (Deyrup and Atkinson 1987), and now is distributed throughout the state. In the Gainesville, Florida area it is abundant in urban, agricultural, and forested areas.

We observed damaging attacks on potted saplings of Shumard oak (Quercus shumardii Buckl.) and Drake elm (Ulmus parvifolia Jacq. cv. Drake) in a commercial nursery in Gainesville. It has been reported as a pest of nursery stock and young trees in the Old World tropics (Browne 1961, Schedl 1962) and of peach trees in South Carolina (Kovach and
Gorsuch 1985). It is a potentially serious pest of ornamentals and fruit trees throughout Florida. In early 1999 traps in Alachua County yielded more specimens of this beetle than were caught in the previous four years (J.L. Foltz, unpublished data).

\section{Description}

Like other species of the tribe Xyleborini, the head of $X$. crassiusculus is completely hidden by the pronotum in dorsal view, the antennal club appears obliquely cut, and the body is generally smooth and shininy. Xylosandrus spp. are distinguished from related genera (Xyleborus, Xyleborinus, Ambrosiodmus) by the stout body, truncate elytral declivity, and non-contiguous procoxae. Female $X$. crassiusculus are 2.1-2.9 mm long, stout bodied; the mature color is dark reddish brown, darker on the elytral declivity. Males are much smaller and differently shaped than females, being only $1.5 \mathrm{~mm}$ long with a radically reduced thorax and a generally "hunch-backed" appearance. Males are flightless, like those of other xyleborines. X. crassiusculus is distinguished from related species in the southeastern

1. This document is EENY-131 (originally published as DPI Entomology Circular No. 310), one of a series of Featured Creatures from the Entomology and Nematology Department, Florida Cooperative Extension Service, Institute of Food and Agricultural Sciences, University of Florida. Published: May 2000. Revised: June 2000. This document is also available on Featured Creatures Website at http://creatures.ifas.ufl.edu. Please visit the EDIS Website at http://edis.ifas.ufl.edu. Additional information on these organisms, including many color photographs, is available at the Entomology and Nematology Department website at http://entnemdept.ifas.ufl.edu/ and the Division of Plant Industry website at http://www.doacs.state.fl.us/ pi/.

2. T. H. Atkinson, J. L. Foltz, R. C. Wilkinson, and R. F. Mizell, Entomology and Nematology Department, University of Florida, Gainesville, FL.

The Institute of Food and Agricultural Sciences is an equal opportunity/affirmative action employer authorized to provide research, educational information and other services only to individuals and institutions that function without regard to race, color, sex, age, handicap, or national origin. For information on obtaining other extension publications, contact your county Cooperative Extension Service office. Florida Cooperative Extension Service/Institute of Food and Agricultural Sciences/University of Florida/Christine Taylor Waddill, Dean. 
United States by its large size (females of other species are 1.3-2.0 mm long), and the dull, densely granulate surface of the declivity (smooth and shining in other species). Larvae are white, legless, "C" shaped, and have a well developed head capsule. They are not distinguishable in any simple way from those of other Scolytidae or most Curculionidae.

\section{Synonyms}

Phloeotrogus crassiusculus Motschulsky, Xyleborus crassiusculus (Motschulsky), Xyleborus semiopacus Eichhoff, Xyleborus semigranosus Blandford, Dryocoetes bengalensis Stebbing, Xyleborus mascarenus Hagedorn, Xyleborus okoumeensis Schedl, Xyleborus declivigranulatus Schedl.

\section{Distribution}

The native range of $X$. crassiusculus is probably tropical and subtropical Asia, and it is widely introduced elsewhere. It is currently found in equatorial Africa, India, Sri Lanka, China, Japan, Southeast Asia, Indonesia, New Guinea, South Pacific, Hawaii, and the southeastern United States (Wood 1982, Kovach and Gorsuch 1985, Chapin and Oliver 1986, Deyrup and Atkinson 1987).

\section{Biology}

Females bore into twigs, branches, or small trunks of susceptible woody plants, excavate a system of tunnels in the wood or pith, introduce the symbiotic ambrosial fungus, and produce a brood. Like other ambrosia beetles, they feed on ectosymbiotic fungi which they introduce into their tunnels and cultivate and not the wood and pith of their hosts. Eggs, larvae, and pupae are found together in the tunnel system excavated by the female. There are no individual egg niches, larval tunnels, or pupal chambers. It breeds in host material from 2 to $30 \mathrm{~cm}$ in diameter, although small branches and stems are most commonly attacked. Attacks may occur on apparently healthy, stressed, or freshly cut host material. High humidity is required for successful reproduction. Attacks on living plants usually are near ground level on saplings or at bark wounds on larger trees (Browne 1961, Schedl 1962). Females remain with their brood until maturity.
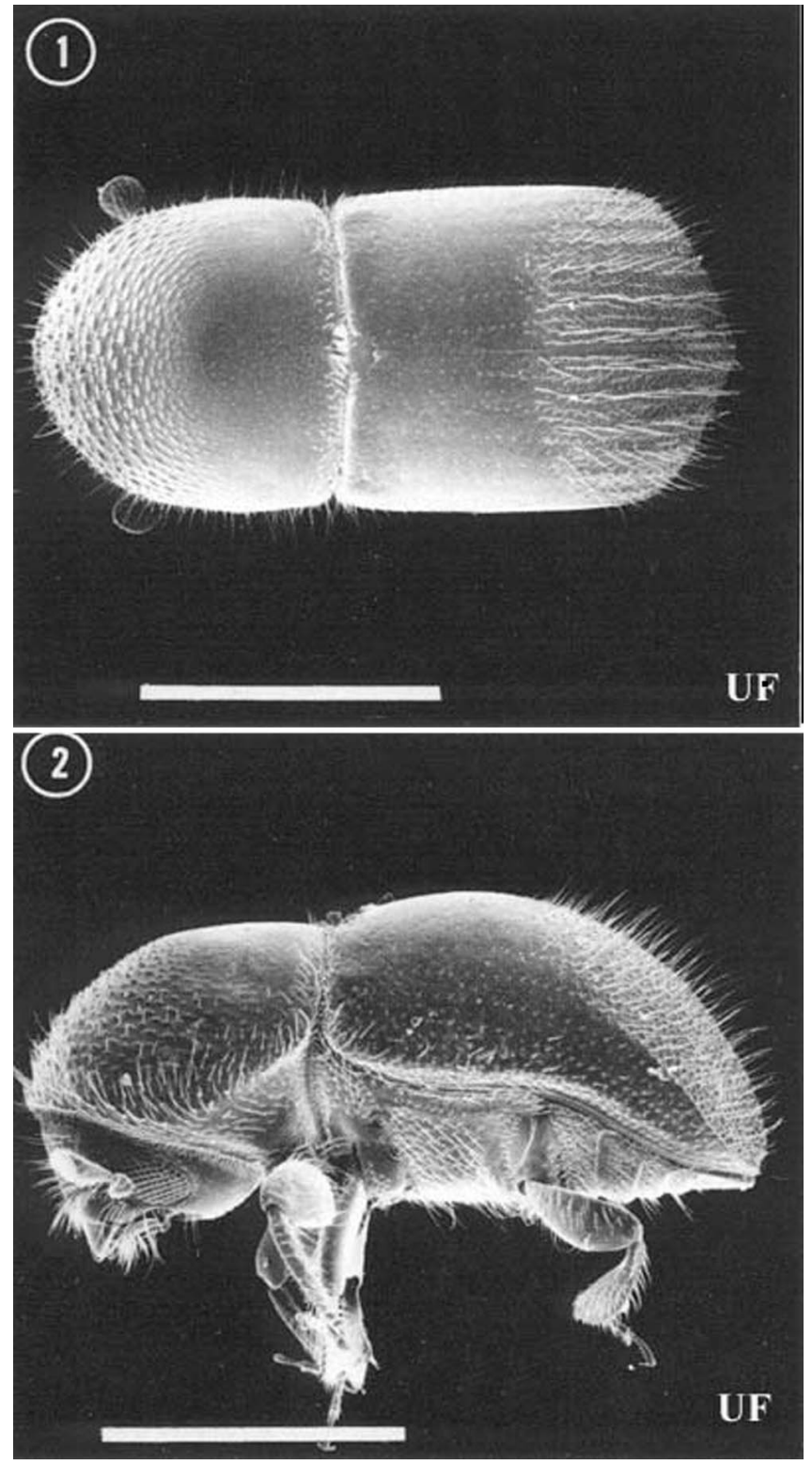

Figure 1. Dorsal (top) and lateral (bottom) views of a female Xylossandrus crassiusculus (Motschulsky), commonly called the "Asian ambrosia beetle." The white line in each photograph represents $1.0 \mathrm{~mm}$. Like other species of the tribe Xyleborini, the head of $X$. crassiusculus is completely hidden by the pronotum in dorsal view, the antennal club appears obliquely cut, and the body is generally smooth and shining. Xylosandrus spp. are distinguished from related genera by the stout body, truncate elytral declivity, and non-contiguous procoxae. Credits: Thomas H. Atkimson, University of Florida

Males are rare, reduced in size, flightless, and presumably haploid. Females mate with their brother(s) before emerging to attack a new host. 

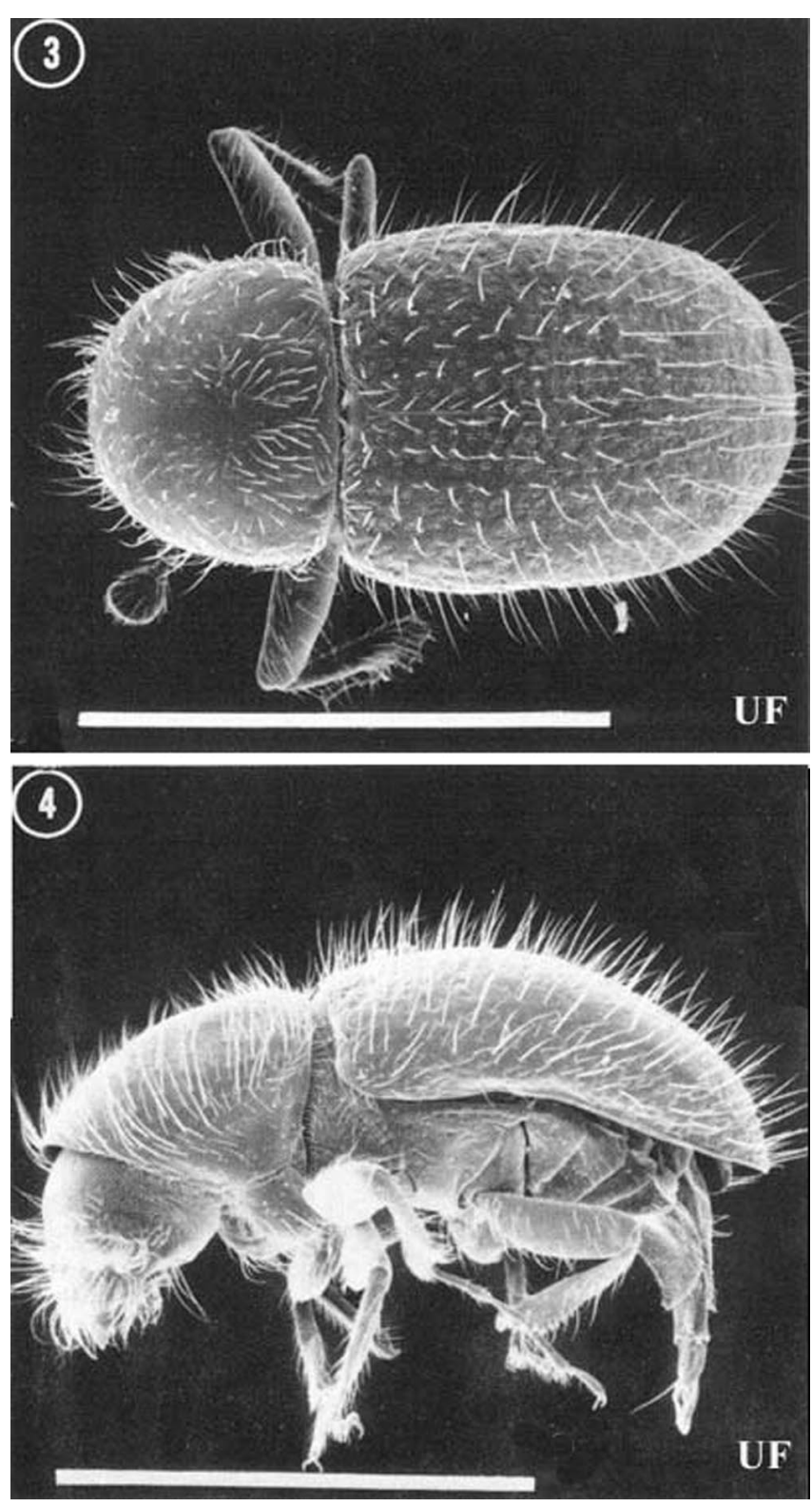

Figure 2. Dorsal (top) and lateral (bottom) views of a male Xylossandrus crassiusculus (Motschulsky), commonly called the "Asian ambrosia beetle." The white line in each photograph represents $1.0 \mathrm{~mm}$. Males are about $1.5 \mathrm{~mm}$ long, much smaller than females. Their shape is also distinctive, characterized by a radically reduced thorax and a generally "hunch-backed" appearance. Like other species of xyleborines, males are flightless and rarely encountered outside their brood gallery. Credits: Thomas H. Atkimson, University of Florida

\section{Hosts}

$X$. crassiusculus is capable of breeding in a wide variety of hosts. Known hosts in the U.S. include peach, plum, cherry, persimmon, golden rain tree, sweetgum, Shumard oak, Chinese elm, sweet potato, and magnolia. Bradford pear and pecan as hosts

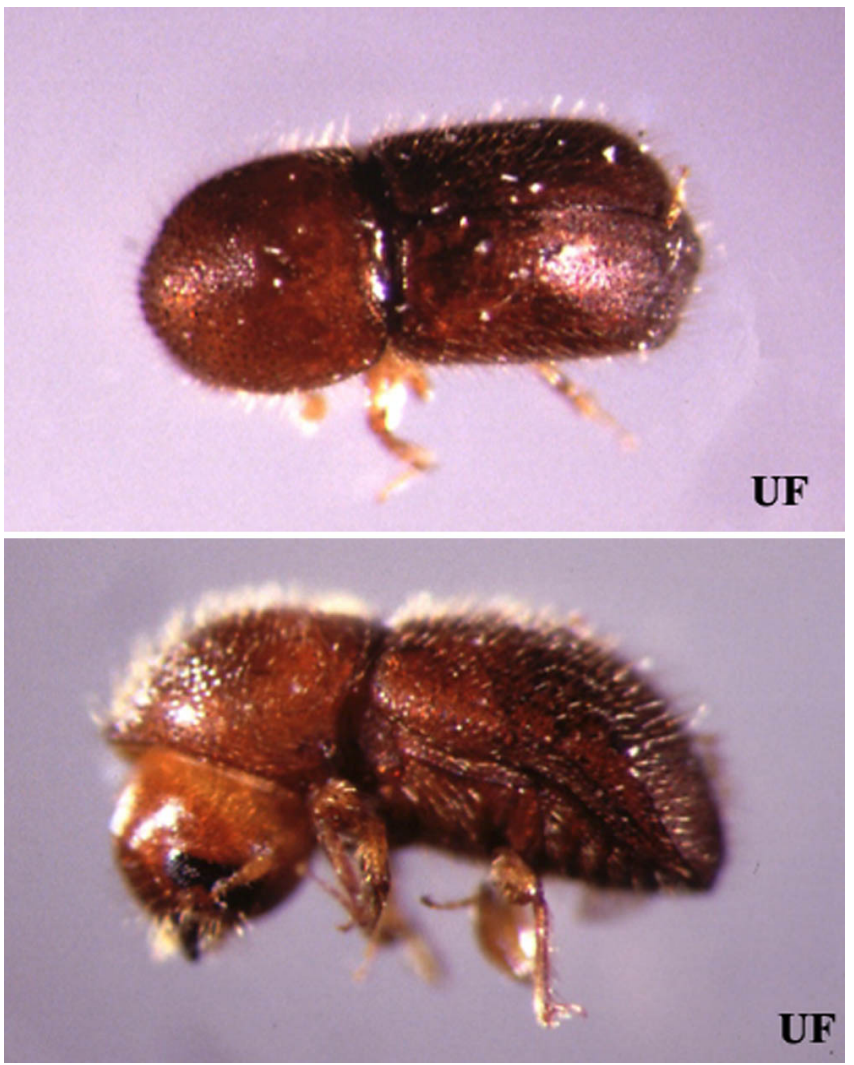

Figure 3. Dorsal (top) and lateral (bottom) views of a female Xylossandrus crassiusculus (Motschulsky), commonly called the "Asian ambrosia beetle." Female $X$. crassiusculus are 2.1-2.9 mm long, stout bodied; the mature color is dark reddish brown, darker on the elytral declivity. $X$. crassiusculus is distinguished from the other two Xylosandrus species in the southeastern United States by its larger size (females of other species are only 1.3-2.0 $\mathrm{mm}$ long), and the dull, densely granulate surface of the declivity (smooth and shining in other species). Credits: Paul M. Choate, University of Florida

commonly attacked in Florida and in the Southeast. Schedl (1962) listed 124 hosts, mostly tropical, in 46 families including coffee, cacao, mango, papaya, Australian pine, rubber, camphor, mahogany, tea, and teak. In May, 2000 a nursery grower submitted samples of crape myrtle infested with this beetle. This popular ornamental plant is already known as a host for $X$. crassiusculus.

\section{Damage}

Large numbers of attacks were found in Shumard oaks along the lower $1 \mathrm{~m}$ of stem in $3 \mathrm{~m}$ saplings with no other symptoms of disease, attack by other insects, or visible stress. Female beetles were boring into green, fresh, unstained portions of the stems. Visible symptoms included wilted foliage and 


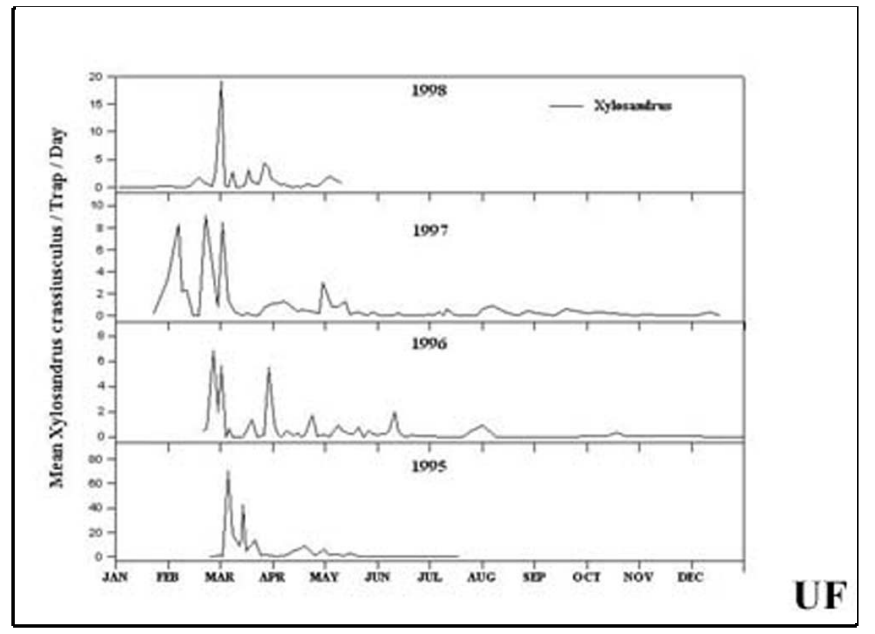

Figure 4. Seasonal emergence and flight period of adult Asiatic ambrosia beetles, Xylosandrus crassiusculus (Motschulsky), at Monticello, Florida 1995-1998 as determined from trapping around nurseries using the Kovach plexiglass trap baited with ethyl alcohol. Females are trapped most frequently during the spring and it is at this time they are most likely to infest nursery-grown trees. Smaller numbers are collected in the summer and fall. Only during the coolest winter months are hardwood logs somewhat safe from ambrosia beetle infestation. Credits: R.F. Mizell, University of Florida

strings of boring dust from numerous small holes. The large numbers of attacks apparently resulted in the death of the trees. Large Drake elm saplings showed isolated attacks on the lower stems which did not directly kill plants. Subsequently, large cankers formed at the site of attacks, in some instances, resulting in the death of trees by girdling. This type of damage is similar to that reported by Browne (1961) and Schedl (1962). Kovach and Gorsuch (1985) reported attacks on branches of apparently healthy young peach trees in coastal South Carolina.

$X$. crassiusculus was a major component of an ambrosia beetle infestation in the sapwood of sweetgum logs in a Chiefland, Florida millyard during September, 1999. Clearly, infestations are not limited to small living trees nor does flight occur only in the Spring. The millyard problem was basically due to storing too many logs too long before processing. Logs were cheap at the time and the mill had a six month rather than a one month inventory. The mill ended up losing more than it had saved by purchasing an excess inventory at low prices.

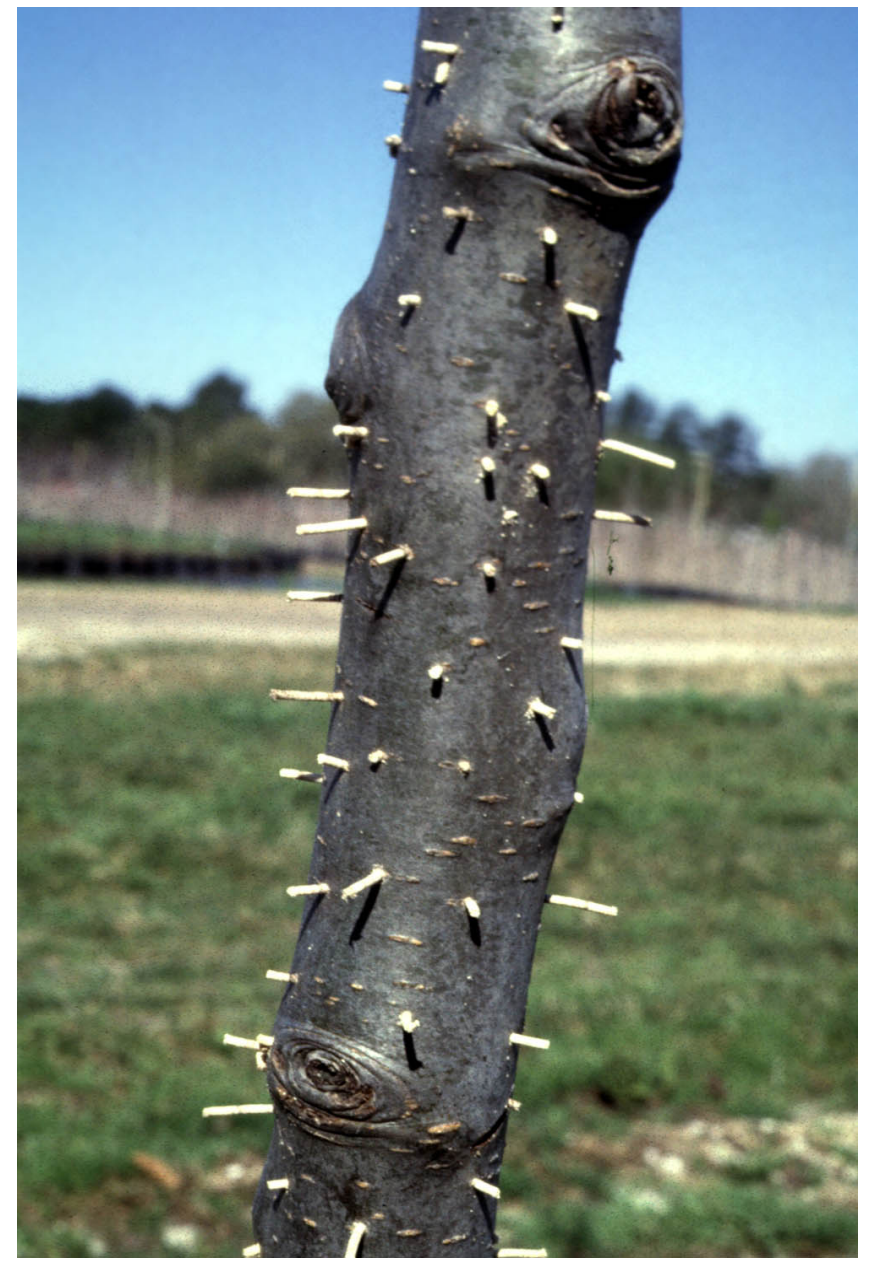

Figure 5. Asiatic ambrosia beetles, Xylosandrus crassiusculus (Motschulsky), attack the trunk of the tree and push the frass out of galleries in a typical toothpick fashion. The beetles innoculate the galleries with ambrosia fungus on which the brood feeds. Credits: R.F. Mizell, University of Florida

\section{Management}

Pyrethroids have been found to provide control of attacking adults if applied prior to the closing of the galleries with frass. Once the beetles are in the tree and have frass packed in the entry holes they are isolated from the outside. If infestations occur, affected plants should be removed and burned and trunks of remaining plants should be treated with an insecticide labeled for this pest or site and kept under observation. Any obvious conditions causing stress to trees should be corrected.

\section{Selected References}

Anderson, D.M. 1974. First record of Xyleborus semiopacus in the continental United States 


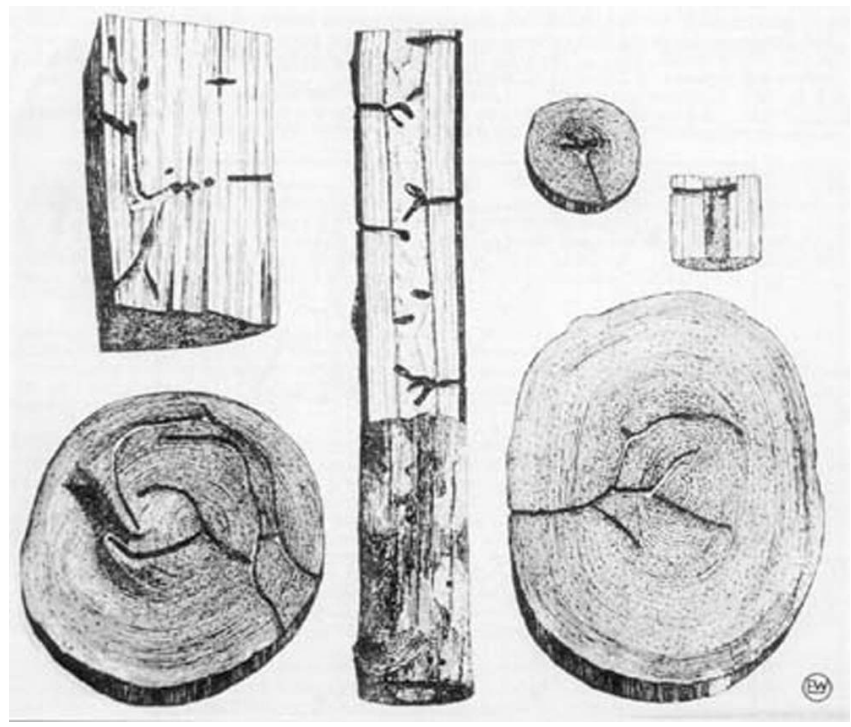

Figure 6. Galleries of Xylossandrus crassiusculus (Motschulsky), commonly called the "Asian ambrosia beetle," in different size host tissues. Gallery patterns vary with the diameter and species of host material. In small diameter material the gallery will go in a few millimeters and then enlarge into a cavelike brood chamber with several branch galleries. In larger material, the brood galleries are more elongate and the branch galleries are longer and more numerous. Credits: Schedl (1962)

(Coleoptera: Scolytidae). U.S. Dept. Agric. Coop. Econ. Insect Rept. 24: 863-864.

Bambara, S., K. Sorensen and J. R. Baker. (August 1998). "The Asian ambrosia beetle." http://www.ces.ncsu.edu/depts/ent/notes/ Ornamentals_and_Turf/trees_contents/orn_t111/ not111.html. (May 12, 2000).

Browne, F.G. 1961. The biology of Malayan Scolytidae and Platypodidae. Malayan Forest Records 22: 1-255.

Chapin, J.B., and A.D. Oliver. 1986 New records for Xylosandrus and Xyleborus species (Coleoptera: Scolytidae). Proc. Ent. Soc. Wash. 88: 680-683.

Deyrup, M.A., and T.H. Atkinson. 1987. New distribution records of Scolytidae from Indiana and Florida. Great Lakes Ent. 20: 67-68.

Ellis, H.C. and D.L. Horton. (January 2000). "Asian ambrosia beetle, Xylosandrus crassiusculus (Motschulsky)."

http://www.bugwood.caes.uga.edu/factsheets/99010.html. (May 12, 2000).

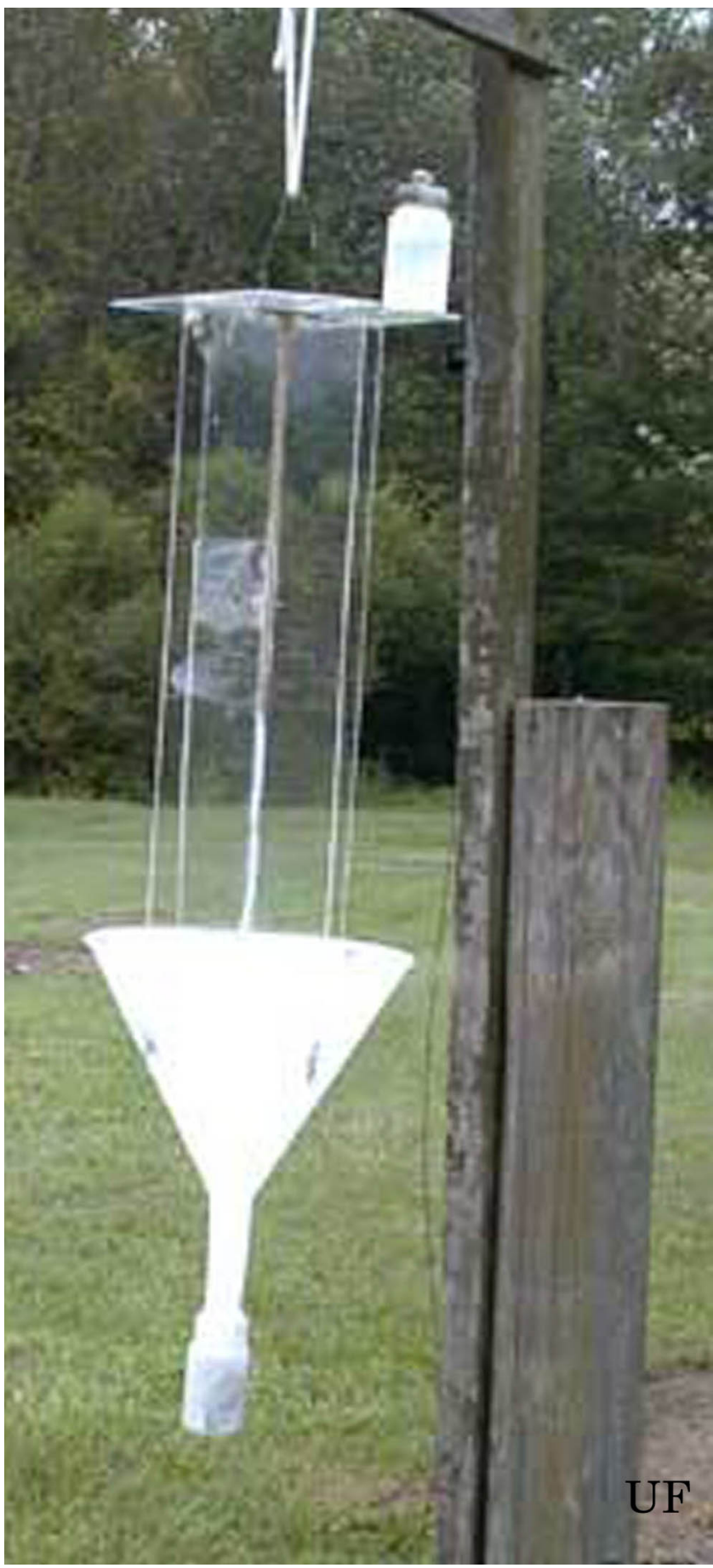

Figure 7. Emerging Asiatic ambrosia beetles, Xylosandrus crassiusculus (Motschulsky), can be trapped using an ethyl alcohol bait trap. Credits: R.F. Mizell, University of Florida

Hudson, W. and R. F. Mizell. 1999. Management of Asian ambrosia beetle, Xylosandrus crassiusculus, in nurseries. Proc. So. Nurs. Grow. Assoc. 44:198-201. 
Kovach, J., and C.S. Gorsuch. 1985. Survey of ambrosia beetle species infesting South Carolina peach orchards and a taxonomic key for the most common species. J. Agric. Ent. 2: 238-247.

Mangold, J.R., R.C. Wilkinson, and D.E. Short. 1977. Chlorpyrifos sprays for control of Xylosandrus compactus in flowering dogwood. J. Econ. Ent. 70: 789-790.

Mizell, R. F., A. Bolques, and P. Crampton. 1998. Evaluation of insecticides to control the Asian ambrosia beetle, Xylosandrus crassiusculus. Proc. So. Nurs. Grow. Assoc. 43:162-165

Schedl, K.E. 1962. Scolytidae und Platypodidae Afrikas. II. Rev. Ent. Mozambique 5: 1-594.

Short, D.E., R.F. Mizell, and T.R. Fasulo. (1998). Woodybug: A knowledgebase of pest and beneficial arthropods of Florida woody ornamentals. UF/IFAS. CD-ROM.

Solomon, J.D. 1995. Guide to insect borers of North American broadleaf trees and shrubs. Agric. Handbk. 706. Washington, DC: U. S. Dept. Agric., Forest Service. 735 p.

Wood, S.L. 1982. The bark and ambrosia beetles of North and Central America (Coleoptera: Scolytidae), a taxonomic monograph. Great Basin Naturalist Mem. 6: 1-1359. 